\title{
Where is Visual Culture in Contemporary Theories of Media and Communication?
}

\author{
KARIN BECKER
}

I.

Theory and research into visual culture continue to be seen as peripheral to the field of media and communication theory, despite the centrality of image flows and visual technologies in both the private and public spheres of contemporary media. This article addresses this lacuna, first by elaborating central concepts and theoretical tenets from the field of visual culture, and then, by suggesting how they can contribute to critical reflective analysis of media and communication, viewed both historically and in the present media environment.

But first, a few words about the place of the image in our time. The contemporary condition is often described as a state of being surrounded, even bombarded by images. The condition is also characterized as an image flow, increasing in its intensity as the means and sources of image production and distribution continue to expand geometrically. Pictures are said to be the most common way of spreading information, of making an impact, of expressing oneself, of influencing others. Intimately intertwined with the development of new information technologies, this "new" culture of visual display has been celebrated as promising a pluralistic and egalitarian future, unfettered by the old linear competencies required by a text-based analogic culture.

This celebration of the image explosion has not gone unchallenged, however. From many quarters the expanding flow of images is seen as a threat, to traditional forms of literacy and learning, to established cultural values and expression, to the sense of order promised by familiar discursive forms, including, it must be said, journalism. The deepseated ambivalence toward images in western culture (cf Mitchell 1994) has resurfaced in response to the intensified image environment in two ways. First, is the anxiety over the presumed "power of images" and fear of their influence. This is evident whenever images figure in sharp debates, often verging on moral panics over issues such as violence in news and entertainment media, invasions of privacy and the effects of advertising. The second ambivalence is directed toward the ways new technologies and forms of display alter conceptions of the image itself and its authority. This reaction can be seen, for example, in conflicts over the photograph and its representational authority in the "digital age" (cf. Lister 1995), and in debates over the forms and significance of post-modern art.

Despite the fact that the so-called image explosion and the debates it engenders are inextricably woven into contemporary mass communication, they remain marginal to the 
field of media and communication studies. The question raised in the title of this article can therefore be seen as primarily rhetorical. For a majority of scholars in this field, the image remains a troubled and undertheorized aspect of their research. A common solution to the problem is to ignore the media's visuality altogether. At the same time, research which takes its point of departure in media's visual aspects is seen as peripheral to the field, and the scholars who make these issues the focus of their work are considered "narrow" in their orientation. This state of affairs suggests that the ambivalence toward the image is embedded in the field itself, in a self-image about what media studies, with roots in journalism, are really about. Addressing this issue would require a critical examination of the history of the field, and is beyond the scope of this article. Although the history of journalism will be referred to at several points in what follows, here the focus is on the relatively new area of inquiry known as visual culture and how its theoretical perspectives may contribute to the field of media and communication studies.

\section{II.}

The study of "visual culture" has emerged over the past fifteen years across a range of disciplines, including art history, film studies, comparative literature, anthropology and museology, as well as regional and cultural studies, in order to take account of the visuality of their objects of study. This explosion of interest in visuality across the humanities and social sciences, giving rise to a flood of texts, cross-disciplinary interest groups and several new journals, can itself be seen as evidence of a "visual turn" in the study of culture and its artefacts (Mitchell 1994). The study of visual culture cannot be seen as a unified field of inquiry, for it lacks a common paradigm, and is characterized by lively debates over its object domain, that is, what it actually studies. The term itself is ambiguous, implying on the one hand that culture as we know it is in the throes of becoming more visual, requiring thereby new theories and modes of inquiry to understand it. On the other hand, the term suggests that the new field is directed toward visual culture and its artefacts, isolating them from other cultural forms. The problems of the term are amplified by many of its practitioners who glide freely between these two meanings of visual culture, falling in to what Mieke Bal correctly refers to as a highly problematic visual essentialism 'that either proclaims the visual 'difference' - read 'purity' - of images, or expresses a desire to stake out the turf of visuality against other media or semiotic systems" (Bal 2003:6). Indeed a clear example of visual essentialism can be found in the field of media and communication, where the study of images has traditionally been dominated by methods developed for "picture analysis" (bildanalys), to the general exclusion of the media's other visual aspects or a theory to account for relationships between visual and non-visual communication forms.

Central to visual culture is the therefore the problem of the object of study. The study of pictures is, as implied by the example above, too narrow, while the study of (visual) culture as a whole is too broad. Further, both chart a trajectory of inquiry that leads away from a theory of the visual that can contribute a new dimension to media and communication studies. What is, or should be, the object of visual culture study? Bal's definition can serve as a starting point:

At the very least, the object domain consists of things we can see or whose existence is motivated by their visibility; things that have a particular visuality or visual quality that addresses the social constituences interacting with them (Bal 2003: 8). 
Although the objects are "things we can see", a critical aspect of this definition is that it includes visuality as a social interactant. What is visible is not self-evident but arises out of a set of social and cultural exigencies that create the conditions for seeing a particular phenomenon or artefact. In order for it to be considered visual, it must fit into a meaningful structure of information and knowledge. Becoming a viewer assumes that one has learned to approach an agreed set of objects as both visible and visual, that is as both seeable and worth looking at. Understanding this complex and highly selective cultural process is critical to the study of visual culture and places visuality itself at the focus of inquiry. This is why simply expanding the set of artefacts to be included in the study of visual culture misses the mark, unless it has been preceded by the question of what is considered visual in that particular set of cultural and historical circumstances.

III.

Elsewhere I have argued that the study of visual culture requires an interrogation of the visual and its place in specific life worlds, including its relationship to other ways of sensing and knowing. This means considering visuality, that is, the meanings associated with seeing and visual forms of expression, as embedded in and arising out of cultural practice. Interrogating the visual includes a deconstruction and critique of how people see, of the values associated with different visual forms, of the power relations that arise in the construction and dissemination of these forms, and how they come to be used in the structuring of knowledge and practice in daily life (Becker 1998).

To describe a culture as visual is a misnomer, for no culture is exclusively visual. Yet all cultures have a visual aspect. In every culture one can find shared knowledge, ways of knowing and the webs of significance they give rise to that are based in visuality. One can locate specific ways of seeing that are expressed in visual forms and that claim their authority through a set of common understandings and experiences. Beginning with Foucault's analysis of the "visible and the articulable" as distinct knowledge systems with different formations (1972), cultural theory has had the means to examine the respective power of these knowledge systems, and to trace the rising authority of the visual as a foundation of culture.

This means that visual culture is not in the first place about images at all. Nor is it about the technologies used to generate and distribute images. Instead the term visual culture describes a particular relationship between seeing and knowledge. It is within this relationship that meanings are developed and ascribed to the multiplicity of images generated and distributed as an increasingly accepted if problematized aspect of contemporary daily life. Pictures and new image technologies do not produce visual culture. They are its artefacts.

Let us look at some examples of what this implies. Looking for the origins of photography, Geoffrey Batchen found that the technical knowledge upon which the medium is based had long been in use (Batchen 1997). Optical devices for looking at a scene through a lens had been popular among the European upper class since the Renaissance, and by the $17^{\text {th }}$ century the camera obscura was considered a necessary tool for working out problems of pictorial representation. Experiments with the chemistry of lightsensitive substances and how to make them permanent took place at the same time, but without any apparent interest in coupling together these discoveries with the images projected by the camera obscura. The knowledge on which photography is based had existed for decades until simultaneously at different locations around Europe, the problem arose of using a lens to create an image that could be fixed for later viewing. Within 
a five-year period photography was suddenly "invented" using several different means, not only by Daguerre and Niepce, but as Batchen has traced, also by a host of other experimenters around Europe. The necessary prerequisite, the idea of the photograph, had emerged and provided the impetus for bringing together what had previously been disparate pieces of knowledge to create a new visual form.

Another example can be found in the lapse of time between the invention of photoreproduction techniques and the integration of photography into daily journalism (Becker $1992 / 2003)$. The half-tone process was invented in the 1880s and the first photograph was published in a newspaper shortly thereafter, a phenomenon that noone at the time seems to have paid particular attention to. In the United States, it was not until World War I that a visual interest was created, and several major newspapers began to publish weekly supplements that included photographs from the war. The tabloid press was the first to use photographs on a daily basis, and in the 1920s a sensationalistic journalistic genre quickly took root, based on a mix of large headlines and photographs. The more serious morning newspapers distanced themselves from this genre by avoiding the use of photographs altogether. Here again, it was not the technology which established the conditions for use, but a set of cultural and political circumstances that established the patterns for a visual culture of journalism that would continue in the metropolitan daily press (at least in New York City) for decades. ${ }^{1}$

\section{IV.}

Both of these examples show how, by shifting the point of inquiry away from the visual artefact, one arrives at larger questions of how particular cultural forms arise and the meanings associated with them. This in turn can elucidate the relationship between the visual and other forms of knowledge and expression. Vision is, as Micke Bal argues, in the first place inherently synaesthetic (Bal 2003: 9). Seeing is never an exclusively visual experience, but involves other sense-laden and sense-based activities, such as listening, reading, movement and touch. This 'impurity' of vision has nothing to do with media per se; it is important that we not consider the visual synaesthetic experience as an artefact of mixed media, of texts that consist of various combinations of words, pictures, sound or (referring to the internet) tactility. Attempts to separate these different registers inevitably lands in the problematic project of producing or re-producing a hierarchy of textual forms (Mitchell 1994). (When a reader looks at a newspaper photograph and reads the caption, meaning is constructed out of the two forms joined together; one cannot assign the "primary" meaning to one or the other.) Further, such distinctions essentialize a textual form as tied exclusively to a specific sense (we hear music, we see pictures), instead of considering how a text often give rise to a range of sensory experience. From the "pictures" that are formed when reading a novel, to the "smells" that the immigrant can experience when seeing a home video from her homeland, people's experience of media is rarely confined to a single sensory mode. ${ }^{2}$

The meanings associated with particular cultural forms are also intertextual. The ways that seeing and visuality are referred to in written texts can provide keys to understanding the role of vision and its relative authority in a specific cultural context. For example, long before photographs appeared in the press, newspaper accounts frequently referred to photography, using the new medium as a metaphor for the currency and truthfulness of the article. Terms such as "eyewitness news" appeal to the authority of vision within the journalistic enterprise. Indeed it can be argued, with John Hartley, that vision has served as a central metaphor for journalism, a way of knowing that is integrated into 
its culture and ideology (Hartley 1992). Expressions of this suture between the practice of journalism and visions's authoritative position in structures of knowledge are so common as to have become a naturalized aspect of western journalism. Bal argues that the study of metaphors that are used in naturalized form are "an indispensible part of visual culture studies" (Bal 2003: 21).

This suggests, despite admonitions above directed at those who would establish a hierarchy of the senses, that vision nevertheless holds a privileged position within some discourses of knowledge. How did this come to be? A full answer to this question requires a history of vision, so suffice it to state that most cultural theorists, following Foucault, locate the dominance of vision in the early modern era (Foster 1988, Foucault 1977). Foucault used the panopticon, Bentham's device that gave the seer omnipotence over the seen, as the model for the epistemological shift from eighteenth century empiricism to the concept of the modern, transcendental "man" (Foucault 1970). Although premodern cultures may have been ocularcentric, the hegemony of vision in modernity is seen as both historically distinctive and functioning in a different way. The visual field, or that which people apprehend primarily (though not exclusively) through the eyes, dominates life and production (Soussloff 1996). Jonathan Crary was among the first theorists to describe vision as allied with new techniques of observation, and "a profound shift in the way in which an observer is described, figured, and posited in science, philosophy, and in new techniques and practices of vision" (Crary 1988: 31). It is in this broader theoretiucal perspective that the claim can be made for journalism as a visuallybased practice and institution with foundations in the Enlightenment. The changed subjectivity of the observer is the mark of modernity and also, Crary argues, the stimulus for its technologies - including photography and the cinema. Knowledge became allied with the camera's eye as the model of objective truth.

This epistemology has not gone unchallenged, however. In his work Downcast Eyes, Martin Jay describes a "denigration of vision", as many of the major nineteenth century philosophers sought to discredit and downplay the obvious power of vision or ocularcentrality as a foundation of knowledge (1993). He identifies a plurality of "scopic regimes" - alternative ways of seeing and representing the world, in both art and science. ${ }^{3}$ In Jay's analysis, Cartesian perspectivalism and its empowering of the direct gaze is only one model of the observer. The scopic regime that he singles out as having finally come into its own in late modernity is the "madness of vision", first identified with the baroque (Jay 1988:19).

According to these theorists, the rise of visual culture in modernity has been marked by struggles among various forms and techniques of knowledge and knowing. Vision itself as a source of knowledge has been contested, and alternatives to the dominant, hegemonic ways of seeing have been denigrated. Yet we have seen in recent years a "pictorial turn", including a shift in cultural theory toward a vigorous denaturalization of vision. Seeing is no longer taken for granted as biological, but instead is generally understood to be formed through cultural processes. This means that straightforward descriptions of what and how we see are no longer possible; vision itself must be problematized, redirecting inquiry into how particular ways of seeing have been formed and why. In particular, the authority ascribed to the dominant western mode of vision and its products is undergoing an intense deconstruction. The attention to "visual culture" since the early 1990s is one aspect of this process, and a clear sign that the struggle over the centrality of vision in our constructions of knowledge and power is not yet resolved. 


\section{V.}

Sorting through the relationship between vision and knowledge leads inevitably to the relationship between the seer and the seen. What happens when people look? Seeing, like other aspects of knowledge, is not limited to cognition, but is performed in the act of looking. Bal describes the two aspects of this relationship: "In the simplest formulation, knowledge directs and colours the gaze, thereby making visible those aspects of objects that otherwise remain invisible ..., but also the other way around: far from being a feature of the object seen, visibility is also a practice, even a strategy, of selection that determines what other aspects or even objects remain invisible" (Bal 2003: 11). Considering the relationship between the seer and that which is seen as a performance is inconsistent with visual essentialism. A performance perspective has the advantage of forefronting visuality as it is being investigated, without determining in advance the object of vision or its qualities.

Seeing is performed by individuals and also by institutions. Just as it is possible to study how institutions think, it is possible to examine how they see, that is, what is made visible and what is obscured through institutional practices. Museum studies have been enriched by this critical perspective with its focus, not on the objects that are housed in the museum, but the tropes of display used in exhibiting and how these constitute subjects- both the museum visitor and those who are on display. In cultural history museums, one finds different tropes of display used for different social classes, creating "invisible orders of significance". The look of the knower (the institution) is promoted, at the same time that it is made invisible. The museum visitor sees the display of traditional culture as a glimpse into "how it really was", and not as a visual code representing a hierarchy of cultural value (Bennett 1995, cf. Kirshenblatt-Gimblett 1998). This would be a fruitful perspective to apply more broadly in studies of media institutions: What are the invisible orders of signficance that are "on display" and how are these constructed and maintained?

Several years ago I did a study comparing display forms on the front pages of local and national newspapers and found differences in the ways photographs addressed the viewer (Becker 2000). In the local papers I looked at, large photographs of people looking into the camera were common, a look that was reserved for occasional feature photographs on the front pages of national morning papers. Within the institution of journalism, this direct camera gaze is to be avoided, for it violates one of the visual tropes of objectivity - the photographic subject's (apparent) unawareness of being observed. According to professional journalism's "invisible order of significance", a news photograph with the subject looking into the camera is non-professional. Yet on the front page of a local paper, the direct gaze of the person in the photograph is a more personal form of address, to be preferred over the visual constraints of a photograph that "looks" objective. This example illustrates how the study of visual culture of journalism can examine the relationship between the seer and the seen from a perspective that interrogates and reveals orders of significance that the institution employs.

The example also points to another institutional foundation of journalism - the distinction between the public and the private - that has been increasingly challenged by changes in media content in recent years. This is an area where visual culture studies can offer important insights. Again, with parallels to museum studies and art history, the study of media has privileged the public realm. Media studies has been formalized as the study of public discourse, with the result that private meanings and uses of media tend to be marginalized. Even when the private sphere is thematicized in the media, as has been 
increasingly the case in recent years, research into these discourses within media studies is based on a dichotomy between the public and private that privileges public discourse in the media's orders of significance. How is visual culture used to reinforce this dichotomy? What interests does it serve? For example, what are the racial and gender stereotypes that are associated with public and private discourses, respectively? Note that focusing on the visual also can be turned to reveal that which is made invisible within these discourses.

Particularly significant are the insights that a visual culture perspective can provide when the question involves intersections between the public and private spheres in contemporary media. What meanings arise in these situations? Visualizations of the private lives of public celebrities is one such example, including the question of how celebrity is created, to then be "privatized". Another example is the private meanings and uses in memories and family histories of media content and events. Or to turn it around, when do materials from the private sphere enter the public arena through the media? These "transgressions", far from being peripheral to contemporary media and communication, can tell us a great deal about the place of media in everyday life experience. In a recent study of vernacular photography, I came across a startling number of news photographs of journalistic events in which people were carrying their own, private cameras. Some of these portrayed visits to tourist sites that had come into the news, perhaps not too surprising, but others were of the signing of bills into law and of people voting in elections. These small apparatuses, evidence of the desire to have personal visual documents of events that are already available in their extensive media coverage, suggests that people, for whatever reason, attach a greater authenticity to a private photograph than a mass media image (Becker 2002).

The field of media and communication study has been framed within a study of institutions and specific media forms. Even studies of the audience have taken their point of departure in the audience of a specific medium. Yet, media continue to expand in their forms, their uses and their reach, making it increasingly problematic to identify the object of study with a given medium (Bjurström, Fornäs \& Ganetz 2000). Visual culture offers perspectives that address this problem by interrogating visual cultural forms that transgress the boundaries of media (and media studies) and asking what meanings they give rise to in the different settings where they come into play. What histories do they have? Where can they be seen? What different forms do they take? What is forgotten or made invisible as the phenomenon reemerges in new settings? Kari Andén-Papadopoulos' recent study of the history of the photograph of New York firemen raising a flag in the ruins of the World Trade Center is an example, as she traced its use through a range of display forms and interviewed people about what this controversial image meant to them (Andén-Papodopoulos 2003).

Finally, as the examples above demonstrate, visual culture offers a perspective that intervenes in the problematic dichotomy between production and reception that continues to plague media and communication studies. Visuality is a form of knowledge that is performed in the act of looking. That which is seen is not "sent" in any conventional sense of that term, but is constructed in the dynamic relationship between seeing and being seen. Irit Rogoff has noted that "one of the most interesting spects of visual culture [is] that the boundary lines between making, theorizing and historicizing have been greatly eroded and no longer exist in exclusive distinction from one another". (Rogoff 1998: 18) 
VI.

The goal of this article has been to present the central concepts, theoretical tenets, and some of the problems of the rapidly expanding field of visual culture studies. Further, I have attempted to argue for the contribution of visual culture theory to the field of media and communication studies. My examples have been drawn largely from the field and practice of journalism and in particular the press. Television and film studies may have appeared to be the more logical place to turn to for examples of visual media. On the other hand, journalism may well be the branch of media studies which has the most to gain by including the tenets of visual culture in its theory and research. It is within journalism that we find visual essentialism in its clearest form, in the study of pictures intended to complement the study of verbal texts. Until the field extends its theoretical reach beyond the study of pictures and texts as the primary forms of media content, it will be locked in to a set of dichotomies that offer little insight into visuality — a critical aspect of media and communication, both historically and in contemporary daily life.

\section{Notes}

1. In contrast, major Swedish daily newspapers were publishing photographs on their front pages in the 1910s (see Becker, Ekecrantz \& Olsson 2000).

2. A young Iranian immigrant reported this experience when looking at a video a relative had sent her, taken while driving streets in Tehren that she had not seen in 14 years. She claimed that news footage from the city had never had that effect.

3. Film theorist Anne Friedberg provides a feminist critique of the gaze built in to model of the panopticon, arguing that other seeing devices supported a more mobile world view, and that Crary's observer does not account for the feminine gaze (Friedberg(1993).

\section{References}

Andén-Papadopoulos, Kari (2004) Den ikoniska nyhetsbilden som visuell kultur. In Aspers, Patrik; Fuehrer, Paul \& Sverrisson, Árni: Bild och samhälle. Lund: Studentlitteratur.

Bal, Mieke (2003) Visual Essentialism, Journal of Visual Culture 2 (1): 5-32.

Batchen, Geoffrey (1997) Burning with Desire: The Conception of Photography. Cambridge, MA: MIT Press.

Becker, Karin (1992/2003) Photojournalism and the Tabloid Press. In Wells, Liz (ed.) The Photography Reader. London:Routledge, 291-308.

Becker, Karin (1998) Bilden i den visuella kulturen/ The Image and Visual Culture. In Carl Heideken (ed.) Xposeptember Stockholm Fotofestival 1998. Stockholm: Xposeptember, 17-40.

Becker, Karin (2000) The Changing Picture of/on the Newspaper Page. In Becker, Karin; Ekecrantz, Jan \& Olsson, Tom (eds.) (2000). Picturing Politics. Visual and Textual Formations of Modernity in the Swedish Press. Stockholm: Stockholm Univeristy, JMK Skriftserien 2000:1.

Becker, Karin (2002) Fotografier: Lagrade bildminnen. In Becker, Karin; Bjurström, Erling; Fornäs, Johan \& Ganetz, Hillevi: Medier och människor i konsumtionsrummet. Nora: Nya Doxa.

Becker, Karin, Ekecrantz, Jan \& Olsson, Tom (eds.) (2000) Picturing Politics. Visual and Textual Formations of Modernity in the Swedish Press. Stockholm: Stockholm Univeristy, JMK Skriftserien 2000:1.

Bennett, Tony (1995) The Birth of the Museum. History, Theory, Politics. London: Routledge.

Bjurström, Erling; Fornäs, Johan \& Ganetz, Hillevi (2000) Det kommunikativa handlandet. Nora: Nya Doxa. Crary, Jonathan. (1990) Techniques of the Observer: On Vision and Modernity in the Nineteenth Century. Cambridge, MA: MIT Press.

Foster, Hall (ed.) (1988) Vision and Visuality. Seattle: Dia Art Foundation.

Foucault, Michel (1970) The Order of Things. An Archeology of the Human Sciences. New York: Random House.

Foucault, Michel (1972) The Archeology of Knowledge. Trans. A.M. Sheridan Smith. London: Tavistock.

Foucault, Michel (1977) Discpline and Punish: The Birth of the Prison. Trans. Alan Sheridan. New York: Vintage Books. 
Friedberg, Anne (1993) Window Shopping: Cinema and the Postmodern. Berkeley: University of California Press.

Hartley, John (1992) The Politics of Pictures. London: Routledge.

Jay, Martin (1988) Scopic Regimes of Modernity, in Foster (ed.) Vision and Visuality. Seattle: Dia Art Foundation.

Jay, Martin (1993) Downcast Eyes: The Denigration of Vision in Twentieth Century French Thought. Berkeley and Los Angeles: University of California Press.

Kirshenblatt-Gimblett, Barbara (1998) Destination Culture. Tourism, Museums, and Heritage. Berkeley: University of California Press.

Lister, Martin (ed.) (1995) The Photographic Image in Digital Culture. London: Routledge.

Mitchell, W.J.T. (1994) Picture Theory. Chicago: University of Chicago Press.

Rogoff, Irit (1998) Studying Visual Culture. In Nicholas Mirzoeff (ed.) The Visual Culture Reader. London: Routledge.

Soussloff, Catherine M. (1996) Review Article: The Turn to Visual Culture. Visual Anthropology Review, Vol. 12, No. 1: 77-83. 